\title{
Genetic variation of resistance of the cultivated strawberry to crown rot caused by Phytophthora cactorum
}

\author{
Sadia Schafleitner ${ }^{\mathrm{a}, \mathrm{b}}$, Alain Bonnet ${ }^{\mathrm{a}, \mathrm{b}}$, Nicole Pedeprat ${ }^{\mathrm{a}, \mathrm{b}}$, , Daniel Rocca $^{\mathrm{a}, \mathrm{b}}$, Philippe $_{\text {Chartier }}^{\mathrm{c}}$ \\ and Béatrice Denoyes ${ }^{\mathrm{a}, \mathrm{b}, *}$ \\ a INRA, UMR 1332 de Biologie du fruit et Pathologie, Villenave d'Ornon, France \\ ${ }^{\mathrm{b}}$ Université de Bordeaux, UMR 1332 de Biologie du fruit et Pathologie, Villenave d'Ornon, France \\ ${ }^{\mathrm{c}}$ Ciref Création Variétale Fraises Fruits Rouges, Douville, France
}

Received 4 October 2012; accepted 16 January 2013

\begin{abstract}
Evaluation of strawberry resistance to crown rot caused by Phytophthora cactorum is usually performed on a limited number of genotypes. The major objective of this study was to screen large genetic resources to identify potential parents that can be further used in breeding programs. Plants were inoculated by wounding the crown and placing a mycelium disk on the wound. Firstly, plug and cold stored plants were evaluated for their susceptibility to P. cactorum. Secondly, a total of 107 genotypes was evaluated using cold stored plants. Plug plants were very low affected by the wounding inoculation with P. cactorum whatever the genotype, whereas results obtained using cold stored plants consistently reflected the susceptibility of the genotype to crown rot. By using cold stored plants, we evaluated the susceptibility of 70 varieties and 37 advanced lines. Among the genotypes, we identified varieties such as Cirafine or Cireine with high level of resistance similar to the one of Senga Sengana. These data will be useful for choosing parents in breeding programs and for validation of markers linked to the resistance to P. cactorum.
\end{abstract}

Keywords: Phytophthora cactorum, strawberry, resistance, type of plants

\section{Introduction}

Strawberry plant diseases caused by viruses, bacteria, phytoplasmas, fungi, and nematodes result in severe economic losses in plant and fruit productions. Control of plant diseases using methods that are both economically and environmentally sustainable is essential to provide a regular production. More particularly, management of soilborn pathogens is a challenge when looking for alternatives to methyl bromide, which became banned in 2005 following the Montreal Protocol [1].

One of the major soilborn pathogens in Europe is Phytohthora cactorum (Lebert and Cohn) J. Schröt. This pathogen causes both crown rot and leather rot of fruits [2]. In fields, the first symptoms observed are a stunting of plants or wilting of young leaves and a dissection of the crown reveals a brown necrosis. According to the extension of this necrosis, partial or entire collapse of the plant is observed and plants die when all vascular vessels are disintegrated. In most cases, symptoms of wilt appear first at the upper end of the crown and spread basipetally [3] and roots often are brown discolored. When fruits are infected, they do not ripen and turn leathery in texture. Crown rot symptoms can appear similar to those caused by anthracnose, but crown tissue infected by the anthracnose pathogen usually

*Corresponding author: Béatrice Denoyes. Tel.: +33 557122460; Fax: +33 557122369; E-mail: denoyes@ bordeaux.inra.fr. 
takes on a darker cinnamon discoloration, which is more dark brown in case of crown rot. Diagnostic clinics of root surface scrapings under a microscope might reveal $P$. cactorum oospores in the tissues, furthermore, culturing samples of the pathogen isolated at the border of the necrosis would definitely confirm the presence of this fungus.

In Europe, strawberry crown rot was first reported in Germany in 1950 [4], then in France in 1960' [5]. It was more recently reported in Northern countries of Europe such as Finland in 1991 [6] and Norway in 1992 [7]. Until 2005 , the control of diseases was achieved by soil disinfection using methyl bromide. Today, new cultural practices such as soilless culture or production of plug or tray plants under a scheme of certification [8] limit the development of diseases including crown rot caused by P. cactorum. As these methods do not allow a full control of crown rot, particularly in nurseries of plug or tray plants where recirculating irrigation system may be used, strawberry cultivars resistant to this disease could represent a promising step forwards in reducing plant losses.

Few studies report analyses of susceptibility variability of strawberry to $P$. cactorum. Results of inoculation performed on diploid Fragaria species showed no indication of any of these species being more resistant or susceptible than others to $P$. cactorum and no systematic differences resulting from geographic origin [9]. In the cultivated strawberry, F. $x$ ananassa, variability of susceptibility of genotypes or cultivars was mainly reported in studies comparing different methods of inoculation, [10-14]. A single large study showed that resistance varied greatly between the 31 genotypes that were tested and offering high levels of resistance for further breeding programs [15]. Inheritance of resistance to $P$. cactorum was reported using 50 bi-parental crosses among 20 elite genotypes [16]. Results suggested additive, polygenically inherited resistance, which agreed with several QTLs found in a segregating population [17] and that offspring from crosses could display transgressive segregation with phenotypes covering the scale from highly resistant to very susceptible [15].

This paper describes firstly the effect of the type of plants, tray plants or cold stored plants, on the level of susceptibility to $P$. cactorum after artificial inoculation. Secondly, using cold stored plants, a large collection of 107 cultivated strawberry genotypes including 70 varieties and 37 advanced lines from the breeding program of Ciref was evaluated against crown rot caused by P. cactorum.

\section{Materials and methods}

\subsection{Plant material}

A total of 70 varieties and 37 advanced lines from the breeding program of Ciref was evaluated (Table 1) in the GenBerry project (https://www.bordeaux.inra.fr/genberry/pages/sum.htm). Their description was included in the database released by GenBerry (http://www.bordeaux.inra.fr/eustrawberrydb). Inoculation tests were performed over three successive years.

Cold stored plants were obtained from field nurseries while plug plants were raised under plastic tunnel. Both types of plants had no treatment against $P$. cactorum. After their harvest in December for plug plants, or early January for cold stored plants, they were stored at minus $\_1.5^{\circ} \mathrm{C}$ and $80 \%$ humidity until their inoculation in February or in March.

\subsection{Inoculum production}

The strain S22 of Phytophthora cactorum isolated by J.C. Navatel (Ctifl) was maintained in liquid nitrogen since 2004 at the UREF-INRA-Bordeaux. Cultures were initiated by transferring mycelium loaded potato dextrose agar (PDA)-disks maintained at $-80^{\circ} \mathrm{C}$ from stock cultures to PARB selective medium. For this step, the disks were quickly thawed at room temperature, briefly dipped in sterile water, drained on sterile absorbent paper, and transferred on PDA medium at $23^{\circ} \mathrm{C}$. About 5 days later, when the diameter of the culture had reached 1 to $2 \mathrm{~cm}$, tips of hyphae were transferred on a selective medium (e.g. PARB medium). For the inoculum production, cultures were transferred on V8-oatflakes-agar medium grown in $90 \mathrm{~mm}$ diameter Petri dishes and kept at $23^{\circ} \mathrm{C}$ in a darkroom. Inoculum consisted of $5 \mathrm{~mm}$ diameter mycelium disks sampled from the leading edge of 5-10 days old cultures. Before the first inoculation test of this study, purity, viability and pathogenicity of the strain were checked. 
Table 1

List of genotypes tested for their resistance to Phytophtora cacotorum

\begin{tabular}{|c|c|c|c|}
\hline Genotypes & Ancestral data $^{\mathrm{a}}$ & Country of Origin $^{\mathrm{a}}$ & Year of Release $^{\mathrm{a}}$ \\
\hline Addie & Pantagruella $\times$ MDUS 3816 & IT & 1982 \\
\hline Belle de Mai & - & FR & $-\mathrm{b}$ \\
\hline Belle et Bonne & Madame Moutôt $\times$ Souvenir de Charles Machiroux & FR & 1958 \\
\hline Betty & Pajaro $\times$ CF206 & FR & 2007 \\
\hline Camarosa & Douglas $\times$ Cal 85.218605 & USA & 1992 \\
\hline Cambridge Favourite & F. chiloensis $\times$ Blakemore or $($ Etter Seedling $\times$ Avant Tout $) \times$ Blakemore & GBR & 1947 \\
\hline Candonga & $-\mathrm{b}$ & SP & 2003 \\
\hline Capitola & CN 25 [ = Cal 75.121-101] $\times$ Parker & USA,Calif. & 1992 \\
\hline Capron royale & - & FR & $-\mathrm{b}$ \\
\hline Chandler & Douglas $\times$ Klon C 55 or Douglas $\times$ CAL 72361105 & USA,Calif. & 1980 \\
\hline Charlotte & Mara des bois $\times$ Cal 19 & FR & 2001 \\
\hline Chili Manzanar & $-\mathrm{b}$ & $-b$ & $-\mathrm{b}$ \\
\hline Ciclade & $-\mathrm{b}$ & FR & 1997 \\
\hline Ciflorette & Mamie $\times$ Earliglow & FR & 1998 \\
\hline Cifrance & Scott $\times$ Chandler & FR & 1996 \\
\hline Cigaline & Gariguette $\times$ Earliglow & FR & 1996 \\
\hline Cigoulette & Belrubi $\times$ Pajaro & FR & 1996 \\
\hline Cijosée & Mara Des Bois $\times$ Cal. 18 & FR & 1997 \\
\hline Cilady & Scoot $\times$ Chandler & FR & 1996 \\
\hline Ciloe & Belrubi $\times$ Allstar & FR & 1998 \\
\hline Cirafine & Cla $18 \times$ Mara des bois & FR & 1997 \\
\hline Cirano & Mara Des Bois $\times$ Muir & FR & 1997 \\
\hline Cireine & Scott $\times$ Chandler & FR & 1996 \\
\hline Clery & Sweet Charlie $\times$ Marmolada ${ }^{\circledR}$ Onebor & IT & 2002 \\
\hline Darselect & Elsanta $\times$ Parker & FR & 1996 \\
\hline Docteur Morère & Duc Malakoff $\times$ Palmyre Berger & FR & 1871 \\
\hline Donner & US-634 × Blakemore & USA & 1945 \\
\hline Dover & Florida Belle $\times$ selection USFL-71-1965E & USA & 1980 \\
\hline Dr. Morère & Duc de Malakoff $\times$ Palmyre Berger & FR & 1871 \\
\hline Earlyglow & MDUS 2359 [Fairland $\times$ Midland] $\times$ MDUS 2713 [Redglow $\times$ Surecrop] & USA, MD & 1975 \\
\hline Elsanta & Gorella $\times$ Holiday & NL & 1981 \\
\hline Favette & $($ Surprise des halles $\times$ Regina $) \times($ Aliso $\times$ Pocahontas $)$ & FR & 1976 \\
\hline Gariguette & Belrubi $\times$ Favette & FR & 1976 \\
\hline Georg Soltwedel & Hansa $\times$ Rotkäppchen & GE & 1941 \\
\hline Gorella & Juspa $\times$ american selection US 3763 & NL & 1960 \\
\hline Hative de Caen & Aurore $\times \mathrm{OP}$ & FR & 1928 \\
\hline Havelland & Münchenberger Frühe $\times$ Georg Soltwedel & GE & 1971 \\
\hline Ile de France & Aurore $\times$ OP & FR & $-\mathrm{b}$ \\
\hline Josif Mahomet & $-\mathrm{b}$ & UKR & 1955 \\
\hline Karmen & Georg Soltwedel $\times$ Sparkle & $\mathrm{CZ}$ & 1971 \\
\hline Libération d'Orléans & Everbearer selection from $\mathrm{F} . \times$ ananassa & FR & 1899 \\
\hline Louis Gauthier & Belle de Meaux $\times$ Marguerite Lebreton & FR & 1896 \\
\hline Madame Moutot & Docteur Morère $\times$ Royal Sovereign & FR & 1906 \\
\hline Mamie & Harvester $\times$ Gariguette & FR & 1988 \\
\hline Mara des bois & {$[($ Humi Gento $\times$ Ostara $) \times($ Red Gauntler $\times$ Korona $)]$} & FR & 1992 \\
\hline Marie France & probably an open pollinated seedling & FR & 1955 \\
\hline
\end{tabular}


Table 1

(Continued)

\begin{tabular}{|c|c|c|c|}
\hline \multirow{2}{*}{$\begin{array}{l}\text { Genotypes } \\
\text { Merton Ruby }\end{array}$} & \multirow{2}{*}{$\begin{array}{l}\text { Ancestral data }^{\mathrm{a}} \\
\text { USDA } 3378 \times \text { Early Cambridge }\end{array}$} & \multicolumn{2}{|c|}{ Country of Origin $^{\mathrm{a}}$ Year of Release $^{\mathrm{a}}$} \\
\hline & & GBR & 1965 \\
\hline Mme Lefèvbre & $-b$ & FR & 1900 \\
\hline Mme Leroy-Ladurie & $-b$ & FR & $-{ }^{b}$ \\
\hline Mme Moutot & Docteur Morère $\times$ Royal Sovereign & FR & 1906 \\
\hline Mysowka & $-\mathrm{b}$ & RUS & 1958 \\
\hline Naiad & Oso Grande $\times$ Eris ${ }^{\circledR}$ Civero & IT & 2000 \\
\hline Orléans & Acadie $\times$ Joliette & $\mathrm{CND}$ & 1996 \\
\hline Pajaro & Cal 63.7-101 × Sequoia & USA,Calif. & 1973 \\
\hline Parker & Douglas $\times($ Tufts $\times 63.7 .101)$ & USA,Calif & 1983 \\
\hline Senga Precosa & Regina $\times($ Sparkle $\times$ Eva Macherauch $)$ & GE & 1953 \\
\hline Red Gauntlet & Auschincruive Climax $\times$ New Jersey 1051 [Royal sovereign $\times$ Howard 17] & GBR & 1957 \\
\hline Revada & Auschincruive Climax $\times$ Ada Herzberg & NL & 1956 \\
\hline Royal Sovereign & King of the Earliest $\times$ Laxtons Noble & UK & 1892 \\
\hline Saint Josef & $-b$ & FR & 1892 \\
\hline Sannié & Docteur Morère $\times$ Vicomtesse Héricart de Thury or offsping & FR & 1800 \\
\hline Ségaline & $-\mathrm{b}$ & FR & $-b$ \\
\hline Senga Sengana & Markee $\times$ Sieger & $\mathrm{GE}$ & 1942 \\
\hline Sequoia & Cal $52.16-15 \times$ Cal 51 s $1-1$ & USA,Calif. & 1968 \\
\hline Soquel & Cruz $\times$ Aiko & USA & 1983 \\
\hline Souvenir de Charles Machiroux ' & Tardive de Leopold $\times$ Ville de Paris & FR & 1942 \\
\hline Spaete Leopold & Comet $\times$ Sämling & GE & 1920 \\
\hline Saint Louis d'Orléans & $-\mathrm{b}$ & FR & $-\mathrm{b}$ \\
\hline Saint Pierre & Chandler $\times$ Jewel & $\mathrm{CND}$ & 1989 \\
\hline Surprise des Halles & $-b$ & FR & 1925 \\
\hline Talisman & New Jersey $1051 \times$ Auchincruive Climax & GBR & 1955 \\
\hline Valeta & Sivetta $\times$ Holiday & NL & 1983 \\
\hline Versallaise & $-\mathrm{b}$ & GBR & 1850 \\
\hline Ville de Caen & Empereur du Maroc $\times$ Madame Moutot & FR & 1922 \\
\hline Ville de Paris & Capron royal $\times$ Princess Dagmar & FR & 1929 \\
\hline
\end{tabular}

${ }^{a}$ main data source: Genberry Database, http://www.bordeaux.inra.fr/eustrawberrydb; ${ }^{b}$ no data; ${ }^{c}$ uncertain released year.

\subsection{Inoculation tests}

All plants were placed at $4{ }^{\circ} \mathrm{C}$ three days before inoculation for thawing. Cold stored plants were washed under cold running water on the day before inoculation and their roots were cut $6-8 \mathrm{~cm}$ below the crown.

Plants were inoculated as described before by Pitrat and Risser [10]. After gently wounding crowns using a scalpel to lay a few vascular vessels open, a mycelium of PDA-disk of $5 \mathrm{~mm}$ diameter was placed on the wound and held in place by sealing the crown and the mycelium disk with a plastic film wrapped around the crown. Control plants were likely treated without mycelium disk. Plants were then transplanted into $10-\mathrm{cm}$ plastic pots containing a mixture of pasteurized sand and soil $(1: 3, \mathrm{v} / \mathrm{v})$. Pots were placed in a greenhouse with $22 \pm 4^{\circ} \mathrm{C}$ day temperature and $17 \pm 4^{\circ} \mathrm{C}$ night temperature. High relative humidity, $75-85 \% \mathrm{rh}$, was maintained during the week after inoculation using a fog system. Inoculation tests were performed from end of February to end of April with day length varying from $10 \mathrm{~h} 30$ to $14 \mathrm{~h} 00$ respectively. No extra light was added.

For each experiment, 10 plants were inoculated and five control plants were included to confirm that commercial samples of genotypes were free of diseases. The 10 inoculated plants were randomized in bulks of five in two blocks while the five control plants were placed into a different compartment in the greenhouse to avoid cross contamination 


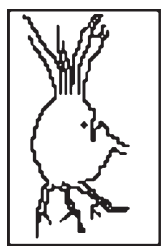

0.5

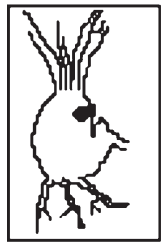

2.0

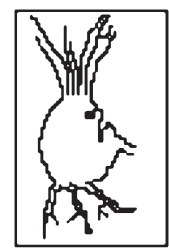

1.0

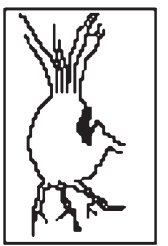

2.0

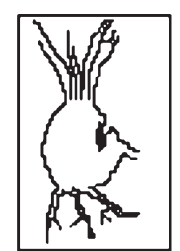

1.0

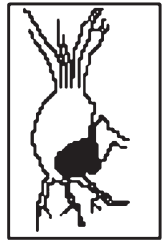

3.0

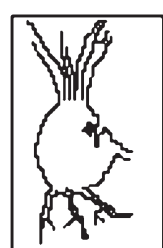

1.5

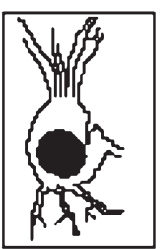

4.0

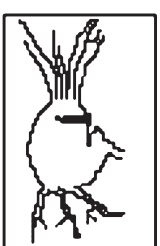

1.5

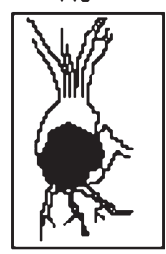

5.0

Fig. 1. Examples of the disease response scored 28 days after inoculation on a scale from 0 to 5 based on the degree of necrosis present in the crown. $0=$ no symptoms, $1=$ necrosis inferior to $1 \mathrm{~mm}, 2=$ necrosis of $2-3 \mathrm{~mm} ; 3=$ necrosis of a quarter to one third of the crown; $4=$ necrosis of half the crown; $5=$ necrosis spread into the entire crown.

by splash dispersal. Experiments were performed twice a year and during three successive years. During the first year, the effect of the type of plants - plug plants and cold stored plants-was evaluated on a limited number of genotypes, while, during the second and the third year, the variability of susceptibility of a large range of genotypes was evaluated using cold stored plants.

\subsection{Disease response}

Eight days after inoculation, the plants were treated against Botrytis cinnerea (Rovral 2g/1). On day 15, the growth of plants was visually assessed on control cold stored plants. When plants failed to grow for some genotypes, we considered that the quality of these cold stored plants was poor and these genotypes were discarded for further analysis for the experiment in which they failed.

Crown disease responses were recorded 28 days after inoculation on a scale of 0 to 5 according to the size of the necrosis. The crown was cut longitudinally in slices of $0.5-1 \mathrm{~mm}$ thickness to have a three-dimensional representation of the necrosis and hence an accurate reading of it. A definition of the main scores assigned to this scale is as follows: $0=$ no symptoms, $1=$ necrosis inferior to $1 \mathrm{~mm}, 2=$ necrosis of $1-2 \mathrm{~mm} ; 3=$ necrosis of $2-3 \mathrm{~mm} ; 4=$ necrosis of half the crown; $5=$ necrosis spread into the entire crown (Fig. 1).

\subsection{Statistical analyses}

Analysis of variance (ANOVA) was performed for disease response followed by a Bonferroni test using SAS software (SAS Institute, Inc., Cary, NC). Since the scale of disease responses comprises 11 steps, with intermediate scores, they were considered as quantitative and subjected to a variance analysis performed with the general linear model procedure (PROC GLM in SAS). A Bonferroni test was used to separate means.

\section{Results}

All inoculation tests were successful and wilt symptoms started to appear on the most susceptible genotypes about two weeks after inoculation. In each of experiment, $10 \%$ of genotypes were removed because at least one of their control plants did not grow 15 days after inoculation. 
Table 2

Results of ANOVA for disease response in strawberry genotypes $(\mathrm{G})$ inoculated with Phytophthora cactorum using two types of plants (Tplt), plug and cold stored plants

\begin{tabular}{lccccc}
\hline Source & $\mathrm{df}$ & Sum of squares & Mean squares & F value & Pr $>\mathrm{F}$ \\
\hline Genotype (G) & 14 & 104.72 & 7.48 & 3.80 & $<0.0001$ \\
Type of plant (Tplt) & 1 & 47.64 & 47.64 & 24.22 & $<0.0001$ \\
Interaction (G $\times$ Tplt) & 13 & 86.97 & 6.69 & 3.40 & $<0.0001$ \\
\hline
\end{tabular}

\subsection{Effect of type of plants}

When plug plants were inoculated, very few symptoms were observed on crowns of the 15 genotypes compared to inoculation on cold stored plants. For most of the genotypes, results of the Student test performed for each genotype lead to classify cold stored plants as more susceptible than plug plants except for Charlotte (data not shown). ANOVA was carried out on crown disease responses scored 28 days after inoculation from the 15 genotypes tested for both types of plants (Table 2). All tested effects, genotype, type of plants and [genotype $\times$ type of plants] interaction, were highly significant. Since the [genotype $\times$ type of plants] interaction was significant, we carried out an ANOVA for each type of plants, followed by a Bonferroni test in order to identify which type of plants was the most consistent for evaluating the susceptibility to $P$. cactorum (Table 3 ). Only results of inoculation on cold stored plants clearly separated the genotypes according to their susceptibility whereas results of inoculation on plug plants gave statistically similar crown disease responses whatever the genotype (Table 3). Therefore, in order to screen for cultivar resistance to $P$. cactorum, we chose hereafter inoculation on cold stored plants rather than on plug plants.

\subsection{Screening test on varieties and advanced lines using cold stored plants}

Among the 107 genotypes, four were evaluated in only one experiment, 40 in two experiments, 25 in three experiments and 38 in all four experiments. ANOVA was carried out using the four experiments performed on two successive years. The effects of genotype and experiment were significant while the effect of [genotype $\times$ experiment] interaction was not significant (Table 4). Therefore, we applied the Bonferroni test on data using all experiments to classify the experiments and the genotypes according to their susceptibility to P. cactorum. The two experiments performed at the end of February in 2009 and 2010 were more severe (disease response means of 1.55 and 1.42 respectively) than the two experiments performed at the end of March the same years (disease response means of 1.22 and 1.18 , respectively).

Genotypes displayed continuous values of crown disease responses from very resistant (e.g. crown disease response of 3.06 for Cambridge Favourite) to very susceptible (e.g. crown disease response of 0.36 for Senga Sengana) with all intermediate degree of susceptibility as shown in Fig. 2 (Table 5). Results of Bonferroni test allowed the classification of the 107 genotypes into overlapping groups. Sixty five cultivars, with crown disease responses ranged from 3.72 (Segaline) to 1.1 (Hative de Caen) (Table 5), displayed a susceptibility statistically similar to the one of the cultivar Cambridge Favourite ranged as very susceptible [10,23]. Nine cultivars displayed a level of resistance similar to the one of Senga Sengana, used as resistant control in numerous works [review in 15]. Among these nine genotypes, Docteur Morere is a very old variety released in 1871. Some genotypes, such as Cigaline, showed large variation between experiments (crown disease responses varied from 1.24 to 2.60) while low variation was observed for other genotypes such as CF3008 (crown disease responses varied from 1.11 to 1.25).

\section{Discussion}

In Europe, the development of cultivation techniques was accompanied by the development of different types of plants. As a consequence, nurseries adapted their cultures to obtain different types of plants such as plug, tray, fresh and cold stored plants. Here, we reported that inoculation of $P$. cactorum on cold stored plants gave more 
Table 3

Susceptibility of 15 varieties and advanced lines according to the type of plant

\begin{tabular}{|c|c|c|c|c|}
\hline Name of genotype/cultivar & Number of plants & Disease response $^{\mathrm{a}}$ & Standard deviation $^{\mathrm{a}}$ & Bonferroni test $^{\mathrm{b}}$ \\
\hline \multicolumn{5}{|l|}{ For cold stored plants } \\
\hline CF1116 & 27 & 2.94 & 2.16 & a \\
\hline Gariguette & 10 & 2.45 & 1.38 & $a b$ \\
\hline Valeta & 5 & 2.30 & 1.72 & $a b$ \\
\hline Ciflorette & 10 & 2.05 & 1.36 & $a b c$ \\
\hline Addie & 20 & 1.78 & 2.20 & $a-d$ \\
\hline Elsanta & 20 & 1.73 & 1.57 & $a-d$ \\
\hline Darselect & 20 & 1.55 & 1.50 & $a-d$ \\
\hline Capitola & 29 & 1.52 & 1.33 & $a-d$ \\
\hline Pajaro & 20 & 1.43 & 1.87 & $a-d$ \\
\hline CF2559 & 19 & 1.18 & 1.68 & $a-d$ \\
\hline CF1778 & 10 & 1.00 & 0.71 & $a-d$ \\
\hline Mara des Bois & 20 & 0.93 & 1.76 & bcd \\
\hline Dover & 10 & 0.20 & 0.35 & $\mathrm{~cd}$ \\
\hline Charlotte & 20 & 0.05 & 0.15 & $\mathrm{~d}$ \\
\hline Cirafine & 10 & 0.00 & 0.00 & $\mathrm{~d}$ \\
\hline \multicolumn{5}{|l|}{ For plug plants } \\
\hline CF1116 & 20 & 0.65 & 1.27 & a \\
\hline Gariguette & 25 & 1.30 & 1.53 & $\mathrm{a}$ \\
\hline Valeta & 15 & 1.23 & 1.74 & $\mathrm{a}$ \\
\hline Ciflorette & 20 & 1.20 & 1.33 & a \\
\hline Addie & 20 & 0.58 & 1.14 & $\mathrm{a}$ \\
\hline Elsanta & 20 & 0.76 & 0.85 & $\mathrm{a}$ \\
\hline Darselect & 20 & 0.35 & 0.52 & a \\
\hline Capitola & 10 & 0.70 & 0.72 & a \\
\hline Pajaro & 19 & 0.45 & 0.83 & a \\
\hline CF2559 & 19 & 0.21 & 0.35 & a \\
\hline CF1778 & 9 & 1.39 & 1.85 & a \\
\hline Mara des bois & 20 & 1.33 & 1.72 & $\mathrm{a}$ \\
\hline Dover & 10 & 0.26 & 0.35 & a \\
\hline Charlotte & 15 & 1.17 & 1.21 & $\mathrm{a}$ \\
\hline
\end{tabular}

${ }^{\text {a }}$ Disease response was scored 28 days after inoculation on a scale from 0 to 5 based on the degree of necrosis present in the crown. Mean and standard deviation of disease response were reported. Cold stored and plug plants were inoculated by depositing a mycelium disk on the wounded crown. ${ }^{b}$ Values in a column followed by different letters are different at $P=0.001$.

Table 4

Results of ANOVA of disease response in strawberry genotypes (G) inoculated with Phytophthora cactorum using cold stored plants. Plants were inoculated in a total of four experiments (exp)

\begin{tabular}{lrccrr}
\hline Effect & df & Sum of squares & Mean squares & F value & Pr $>$ F \\
\hline Genotype $(G)$ & 109 & 1576.43 & 14.46 & 6.05 & $<0.0001$ \\
Experiement $(\mathrm{E})$ & 3 & 82.39 & 27.46 & 11.48 & $<0.0001$ \\
Interaction $(\mathrm{G} \times \mathrm{E})$ & 204 & 567.76 & 2.78 & 1.16 & 0.062 \\
\hline
\end{tabular}




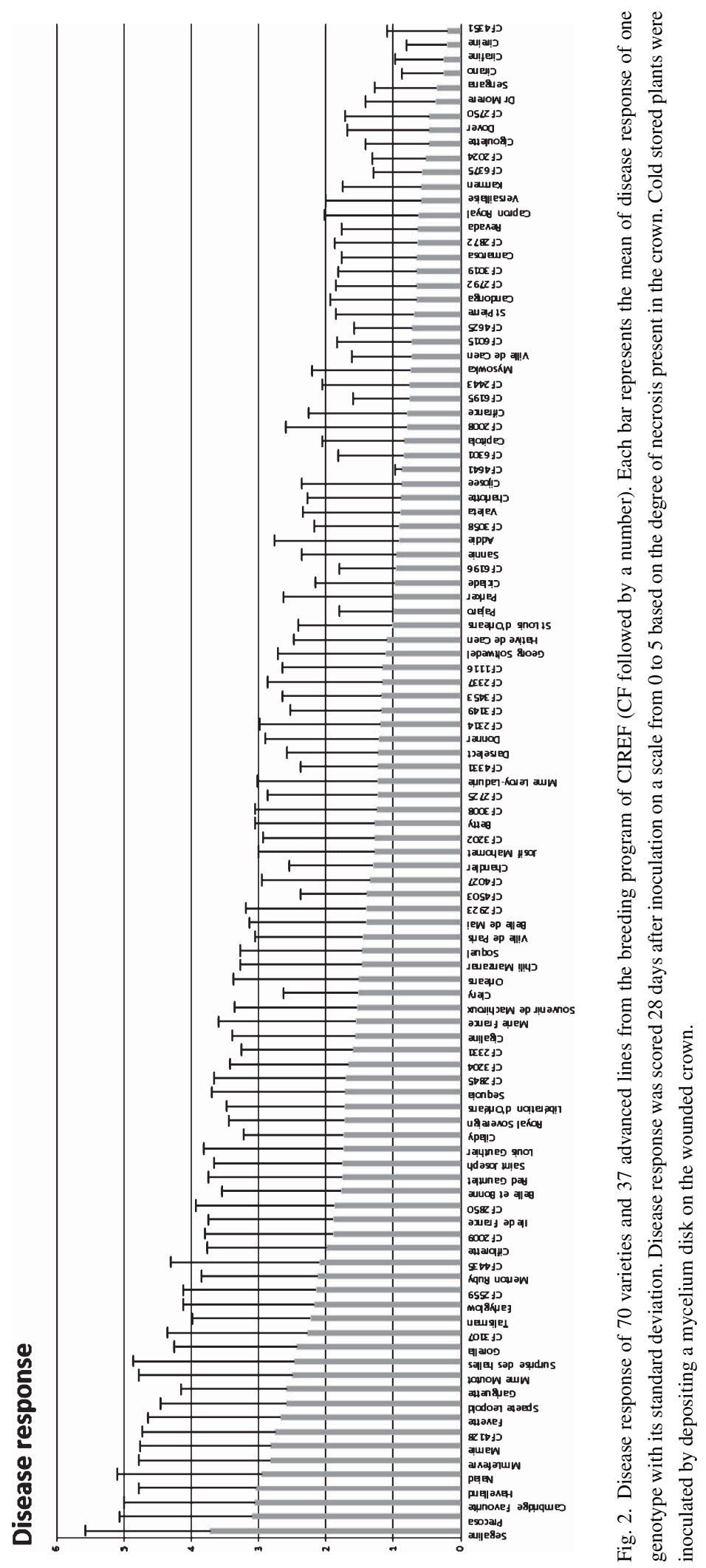


Table 5

Disease response of 70 varieties and 37 advanced lines inoculated with Phytophthora cactorum. Cold stored plants were inoculated with one isolate of $P$. cactorum, $\mathrm{S} 22$, by wounding the crown

\begin{tabular}{|c|c|c|c|c|c|c|}
\hline Genotype & $\mathrm{N}^{\circ} \exp ^{\mathrm{a}}$ & $\mathrm{N}^{\circ}$ Year $^{\mathrm{a}}$ & Freq. $^{\mathrm{b}}$ & DR-mean $^{c}$ & DR-std ${ }^{c}$ & Bonf-class $^{\mathrm{d}}$ \\
\hline Segaline & 3 & 2 & 30 & 3.72 & 1.86 & a \\
\hline Senga Precosa & 4 & 2 & 36 & 3.1 & 1.97 & $\mathrm{ab}$ \\
\hline Cambridge Favourite & 2 & 1 & 17 & 3.06 & 1.94 & $a b$ \\
\hline Havelland & 3 & 2 & 28 & 3.04 & 1.74 & $a b c$ \\
\hline Naiad & 2 & 2 & 13 & 2.96 & 2.14 & $a-d$ \\
\hline MmLefevre & 3 & 2 & 26 & 2.83 & 1.94 & a-e \\
\hline Mamie & 2 & 1 & 17 & 2.82 & 1.94 & a-e \\
\hline CF4128 & 2 & 1 & 18 & 2.75 & 1.98 & $a-f$ \\
\hline Favette & 3 & 2 & 28 & 2.68 & 1.96 & $\mathrm{a}-\mathrm{g}$ \\
\hline Spaete Leopold & 4 & 2 & 33 & 2.59 & 1.87 & $a-h$ \\
\hline Gariguette & 3 & 2 & 25 & 2.58 & 1.57 & $\mathrm{a}-\mathrm{h}$ \\
\hline Mme Moutot & 3 & 2 & 30 & 2.5 & 2.28 & $a-i$ \\
\hline Surprise des halles & 2 & 1 & 19 & 2.47 & 2.39 & $a-j$ \\
\hline Gorella & 2 & 1 & 20 & 2.43 & 1.82 & $a-j$ \\
\hline CF3107 & 2 & 1 & 20 & 2.28 & 2.08 & $\mathrm{a}-\mathrm{k}$ \\
\hline Talisman & 4 & 2 & 37 & 2.24 & 1.75 & $\mathrm{a}-\mathrm{k}$ \\
\hline Earlyglow & 3 & 2 & 30 & 2.18 & 1.94 & $a-1$ \\
\hline CF2559 & 2 & 1 & 20 & 2.15 & 1.96 & $a-1$ \\
\hline Merton Ruby & 3 & 2 & 28 & 2.13 & 1.72 & $a-1$ \\
\hline CF4435 & 1 & 1 & 10 & 2.1 & 2.2 & $a-1$ \\
\hline Ciflorette & 3 & 2 & 40 & 1.99 & 1.78 & $a-1$ \\
\hline CF2009 & 2 & 1 & 20 & 1.9 & 1.89 & $a-1$ \\
\hline Ile de France & 3 & 2 & 30 & 1.9 & 1.84 & $a-1$ \\
\hline CF2850 & 2 & 1 & 20 & 1.88 & 2.05 & $a-1$ \\
\hline Belle et Bonne & 4 & 2 & 40 & 1.78 & 1.76 & $a-1$ \\
\hline Red Gauntlet & 2 & 1 & 19 & 1.76 & 1.99 & $a-1$ \\
\hline Saint Joseph & 4 & 2 & 40 & 1.76 & 1.9 & $a-1$ \\
\hline Louis Gauthier & 2 & 1 & 20 & 1.75 & 2.06 & $a-1$ \\
\hline Cilady & 2 & 1 & 20 & 1.75 & 1.47 & $a-1$ \\
\hline Royal Sovereign & 3 & 2 & 26 & 1.73 & 1.72 & a-1 \\
\hline Libération d'Orléans & 2 & 1 & 20 & 1.73 & 1.74 & $a-1$ \\
\hline Sequoia & 4 & 2 & 37 & 1.72 & 1.98 & $a-1$ \\
\hline CF2845 & 2 & 1 & 19 & 1.71 & 1.95 & $a-1$ \\
\hline CF3204 & 3 & 2 & 30 & 1.67 & 1.75 & b-1 \\
\hline CF2331 & 2 & 1 & 20 & 1.6 & 1.65 & b-1 \\
\hline Cigaline & 4 & 2 & 47 & 1.57 & 1.82 & b-1 \\
\hline Marie France & 3 & 2 & 27 & 1.56 & 2.04 & b-1 \\
\hline Souvenir de Machiroux & 4 & 2 & 40 & 1.54 & 1.81 & b-1 \\
\hline Clery & 4 & 2 & 38 & 1.53 & 1.1 & b-1 \\
\hline Orleans & 3 & 2 & 27 & 1.52 & 1.86 & b-1 \\
\hline Chili Manzanar & 4 & 2 & 38 & 1.47 & 1.81 & b-1 \\
\hline Soquel & 3 & 2 & 30 & 1.47 & 1.81 & b-1 \\
\hline Ville de Paris & 3 & 2 & 26 & 1.46 & 1.59 & b-1 \\
\hline Belle de Mai & 4 & 2 & 35 & 1.41 & 1.73 & b-1 \\
\hline CF2923 & 4 & 2 & 40 & 1.41 & 1.78 & b-1 \\
\hline
\end{tabular}


Table 5

(Continued)

\begin{tabular}{|c|c|c|c|c|c|c|}
\hline Genotype & $\mathrm{N}^{\circ} \exp ^{\mathrm{a}}$ & $\mathrm{N}^{\circ}$ Year $^{\mathrm{a}}$ & Freq. $^{\text {b }}$ & DR-mean ${ }^{\mathrm{c}}$ & DR-std ${ }^{\mathrm{c}}$ & Bonf-class $^{\mathrm{d}}$ \\
\hline CF4503 & 2 & 1 & 19 & 1.4 & 0.97 & $b-1$ \\
\hline CF4027 & 2 & 1 & 20 & 1.35 & 1.6 & b-1 \\
\hline Chandler & 3 & 2 & 29 & 1.31 & 1.24 & b-1 \\
\hline Josif Mahomet & 4 & 2 & 39 & 1.28 & 1.72 & b-1 \\
\hline CF3202 & 4 & 2 & 38 & 1.28 & 1.65 & b-1 \\
\hline Betty & 2 & 1 & 20 & 1.28 & 1.78 & b-1 \\
\hline CF3008 & 4 & 2 & 34 & 1.25 & 1.81 & b-1 \\
\hline CF2725 & 4 & 2 & 35 & 1.24 & 1.62 & b-1 \\
\hline Mme Leroy-Ladurie & 4 & 2 & 40 & 1.24 & 1.78 & b-1 \\
\hline CF4331 & 2 & 1 & 20 & 1.23 & 1.14 & b-1 \\
\hline Darselect & 2 & 2 & 20 & 1.23 & 1.35 & b-1 \\
\hline Donner & 4 & 2 & 34 & 1.22 & 1.68 & b-1 \\
\hline $\mathrm{CF} 2314$ & 2 & 1 & 20 & 1.2 & 1.78 & b-1 \\
\hline CF3149 & 4 & 2 & 38 & 1.18 & 1.35 & b-1 \\
\hline CF3453 & 2 & 1 & 20 & 1.18 & 1.46 & b-1 \\
\hline CF2337 & 2 & 1 & 19 & 1.16 & 1.7 & b-1 \\
\hline CF1116 & 2 & 1 & 19 & 1.16 & 1.48 & b-1 \\
\hline Georg Soltwedel & 3 & 2 & 29 & 1.12 & 1.59 & b-1 \\
\hline Hative de Caen & 2 & 1 & 20 & 1.1 & 1.38 & b-1 \\
\hline St Louis d'Orleans & 3 & 2 & 30 & 1.02 & 1.39 & $\mathrm{~d}-1$ \\
\hline Pajaro & 2 & 1 & 20 & 1 & 0.81 & $\mathrm{~d}-1$ \\
\hline Parker & 3 & 2 & 29 & 1 & 1.63 & $\mathrm{~d}-1$ \\
\hline Ciclade & 4 & 2 & 40 & 0.99 & 1.17 & $\mathrm{~d}-1$ \\
\hline CF6196 & 2 & 1 & 15 & 0.97 & 0.83 & $\mathrm{~d}-1$ \\
\hline Sannie & 4 & 2 & 37 & 0.96 & 1.4 & $\mathrm{~d}-1$ \\
\hline Addie & 2 & 1 & 19 & 0.92 & 1.85 & $e-1$ \\
\hline CF3058 & 3 & 2 & 25 & 0.92 & 1.26 & e-1 \\
\hline Valeta & 4 & 2 & 40 & 0.9 & 1.45 & $e-1$ \\
\hline Charlotte & 4 & 2 & 63 & 0.89 & 1.38 & e-1 \\
\hline Cijosee & 4 & 2 & 37 & 0.88 & 1.48 & e-1 \\
\hline CF4641 & 2 & 1 & 20 & 0.88 & 0.1 & $e-1$ \\
\hline CF6301 & 1 & 1 & 10 & 0.85 & 0.97 & e-1 \\
\hline Capitola & 2 & 2 & 19 & 0.84 & 1.21 & $e-1$ \\
\hline CF2008 & 1 & 1 & 5 & 0.8 & 1.79 & $f-1$ \\
\hline Cifrance & 2 & 1 & 20 & 0.8 & 1.45 & $f-1$ \\
\hline CF6195 & 2 & 1 & 24 & 0.77 & 0.83 & $f-1$ \\
\hline CF2443 & 3 & 2 & 28 & 0.77 & 1.29 & $f-1$ \\
\hline Mysowka & 3 & 2 & 28 & 0.75 & 1.45 & $f-1$ \\
\hline Ville de Caen & 4 & 2 & 39 & 0.73 & 0.88 & $g-1$ \\
\hline CF6015 & 2 & 1 & 20 & 0.73 & 1.11 & $\mathrm{~g}-1$ \\
\hline CF4625 & 1 & 1 & 9 & 0.72 & 0.87 & $g-1$ \\
\hline St Pierre & 4 & 2 & 37 & 0.7 & 1.15 & $g-1$ \\
\hline Candonga & 4 & 2 & 34 & 0.66 & 1.27 & h-1 \\
\hline CF2792 & 4 & 2 & 44 & 0.66 & 1.2 & h-1 \\
\hline CF3019 & 4 & 2 & 38 & 0.66 & 1.16 & h-1 \\
\hline Camarosa & 4 & 2 & 38 & 0.66 & 1.1 & h-1 \\
\hline
\end{tabular}


Table 5

(Continued)

\begin{tabular}{|c|c|c|c|c|c|c|}
\hline Genotype & $\mathrm{N}^{\circ} \exp ^{\mathrm{a}}$ & $\mathrm{N}^{\circ}$ Year $^{\mathrm{a}}$ & Freq. $^{\text {b }}$ & DR-mean ${ }^{c}$ & DR-std ${ }^{c}$ & Bonf-class $^{\mathrm{d}}$ \\
\hline CF2872 & 2 & 1 & 20 & 0.65 & 1.22 & h-1 \\
\hline Revada & 3 & 2 & 28 & 0.64 & 1.13 & h-1 \\
\hline Capron Royal & 2 & 2 & 20 & 0.63 & 1.4 & h-1 \\
\hline Versaillaise & 4 & 2 & 38 & 0.59 & 1.41 & h-1 \\
\hline Karmen & 4 & 2 & 40 & 0.59 & 1.16 & h-1 \\
\hline CF6375 & 2 & 1 & 20 & 0.58 & 0.71 & h-1 \\
\hline CF2024 & 3 & 2 & 30 & 0.52 & 0.8 & i-1 \\
\hline Cigoulette & 4 & 2 & 38 & 0.47 & 0.95 & $\mathrm{jkl}$ \\
\hline Dover & 2 & 1 & 19 & 0.47 & 1.21 & $\mathrm{jkl}$ \\
\hline CF2750 & 2 & 1 & 15 & 0.47 & 1.25 & $\mathrm{jkl}$ \\
\hline Dr Morere & 4 & 2 & 38 & 0.38 & 1.04 & $\mathrm{kl}$ \\
\hline Senga Sengana & 4 & 2 & 37 & 0.36 & 0.91 & $\mathrm{kl}$ \\
\hline Cirano & 4 & 2 & 40 & 0.26 & 0.62 & $\mathrm{kl}$ \\
\hline Cirafine & 4 & 2 & 40 & 0.26 & 0.72 & $\mathrm{kl}$ \\
\hline Cireine & 4 & 2 & 39 & 0.21 & 0.59 & 1 \\
\hline CF4351 & 2 & 1 & 20 & 0.2 & 0.89 & 1 \\
\hline
\end{tabular}

a Number of experiment and Number of years. ${ }^{b}$ Number of inoculated cold stored plants. ${ }^{\mathrm{c}}$ Disease response was scored 28 days after inoculation on a scale from 0 to 5 based on the degree of necrosis present in the crown. Mean and standard deviation of disease response were reported. Cold stored plants were inoculated by depositing a mycelium disk on the wounded crown. ${ }^{\mathrm{d}}$ Bonferroni test was carried out for all experiments. Values in a column followed by different letters are different at $P=0.001$.

consistent results than on plug plants, which are plants obtained in July from runners and raised under tunnel until they were placed at $-1.5^{\circ} \mathrm{C}$ for chilling requirement. The last were very low affected by the wounding inoculation with $P$. cactorum whatever the genotype, whereas results obtained using cold stored plants consistently reflected the genotype susceptibility of the crown to $P$. cactorum. In addition by using cold stored plants, we reported the largest study on genetic screening for susceptibility to $P$. cactorum in the cultivated strawberry.

In Eikemo et al. [12], authors reported that inoculation of cold stored plug plants gave more uniform results than inoculation on non-cold stored plug plants. Hypothesis of cold storage to shift plants into their most susceptible state was suggested. In our experiment, both types of plants received cold storage treatment, naturally in the nursery field for cold stored plants and controllably in the climatic chamber for plug plants. Low temperature observed in natural conditions would injure crowns more severely and as a result increase their susceptibility to crown rot [18]. Crown rot in cold stored plants could also result of infections prior to cold storage [11]. To avoid this problem, absence of symptoms all along the inoculation test on non-inoculated control plants is critical.

Other factors than the type of plants may influence screening test. One of them is the preparations of inoculum of P. cactorum, which can be prepared as zoospores poured onto the crown $[9,11,15]$, as sporangia added in container [14], as agar disks of mycelium placed on the wounded crown [10], as homogenates of mycelium on strawberry in vitro shoots [13], or V8 juice-vermiculite-oat medium permeated with P. cactorum incorporated in soil [16]. In this study, use of mycelium disks was preferred, because it has given consistent results over several years for disease responses of genotypes and for inoculum preparation. Another factor is the strain used in the screening test since specific interaction can exist between genotypes and isolates as previously described for anthracnose in strawberry $[19,20]$. However, pathogenicity of $P$. cactorum, isolated from crown rot did not show large variability [21, 22] whereas crown rot isolates were different from leather rot isolates [21].

To be an efficient screening test for evaluating resistance to $P$. cactorum, inoculation test was repeated to confirm the level of genotype resistance in addition to the presence of replicates for each experiment. In this study, two years of inoculation test with two tests per year were enough to give consistent results. Variability observed between inoculation tests could be due to the influence of environmental conditions (Pitrat and Risser xxx). In order to standardize the 
protocol and overcome problem of repeatability, control genotypes have to be included in each experiment. In our work, the cultivars Senga Sengana and Cambridge Favourite were useful as resistant and susceptible cultivars $[10,12,23]$.

Strawberry breeding began in England in the late 1700 s, followed by France and Germany. The first selected European cultivars were used as genitors in early American breeding programs, together with American native cultivars [24]. The origin of strawberry and these early breeding practices reduced initial genetic variability. As an example, pedigrees of 134 North American cultivars were traced and shown to originate from only 17 cytoplasmic sources [25]. Despite introgressions of wild strawberry germplasm increased initial diversity of the cultivated strawberry, loss of diversity was observed in modern strawberry cultivars [26, 27]. However, our results showed that advanced lines can display large variability from high to low level of resistance (Table 5). Therefore, breeding for resistance is a powerful strategy for controlling diseases in the cultivated strawberry.

Efficiency of breeding programs could be improved by developing marker assisted selections as developed for anthracnose resistance [19]. Since the mode of inheritance for resistance to $P$. cactorum is likely polygenic [16, 17], which is suggested by the continuum of level of disease resistance in a range of cultivar, a strategy for the identification of QTLs will be developed. Then, markers flanking the most significant QTLs will be used for validation on germplasm. For this strategy, the use of the diploid Fragaria, which genome sequence is available [28] will be very useful, since the octoploid and the diploid genomes are almost collinear [29, 30].

\section{Acknowledgement}

This work was supported by the DG Agriculture (GEN RES 036 project named GENBERRY).

\section{References}

[1] European Commission. The Montreal Protocol, Ed. Office for Official Publications of the European Communities. $2007 ; 24$.

[2] Rose DH. Leather rot of strawberries. J Agr Res 1924;28:357-76.

[3] Maas JL, ed. Compendium of Strawberry Diseases. MN, USA: St. Paul; 1984. p. 138.

[4] Deutchmann VF. Eine Wurzelfäule an Erdbeeren, hervorgerufen durch Phytophthora cactorum (Leb. Et Cohn) Schroet. Nachrichtenblatt des Deutschen Pflanzenschutzdienstes (Braunschweig) 1954;6:7-9.

[5] Molot PM, Nourrisseau JG. Dessèchement printannier du fraisier causé par Phytophthora cactorum. C R Acad Agric France 1966;52:1001-5.

[6] Parikka P. Phytophthora cactorum on strawberry in Finland. Nordisk Jordbruksforskning 1991;73:121.

[7] Stenvsand A, Herrero ML, Talso V. Crown rot caused by Phytophthora cactorum in Norwegian strawberry production. EPPO Bulletin 1999;29:155-8.

[8] OEPP/EPPO. Certification Scheme - Pathogen-tested strawberry - Bulletin OEPP/EPPO. 1994;24:875-889.

[9] Eikemo H, Brurberg MB, Davik J. Resistance to Phytophthora cactorum in Diploid Fragaria Species. HortScience 2010;45:193-7.

[10] Pitrat M, Risser G. Etude de la sensibilité variétale du fraisier à Phytophthora cactorum après contamination provoquée. Ann Amélior Plantes 1977;27:49-60.

[11] Pettitt TR, Pegg GF. Sources of crown rot (Phytophthora cactorum) infection in strawberry and the effect of cold storage on susceptibility to the disease. Annals of Applied Biology 1994;125:279-2.

[12] Eikemo H, Stensvand A, Tronsmo AM. Evaluation of methods of screening strawberry cultivars for resistance to crown rot caused by Phytophthora cactorum. Annals of Applied Biology 2000;137:237-44.

[13] Sowik I, Bielenin A, Michalczuk L. In vitro testing of strawberry resistance to Verticillium dahliae and Phytophthora cactorum. Scientia Horticulturae 2001;88:31-40.

[14] Parikka P. Screening Plant Resistance to Phytophthora cactorum with the Dipping Test. Acta Horticulturae 2009;842:311-4.

[15] Eikemo H, Stensvand A, Davik J, Tronsmo AM. Resistance to crown rot (Phytophthora cactorum) in strawberry cultivars and in offspring from crosses between cultivars differing in susceptibility to the disease. Annals of Applied Biology 2003;142:83-9.

[16] Shaw DV, Hansen J, Browne GT, Shaw SM. Components of genetic variation for resistance of strawberry to Phytophthora cactorum estimated using segregating seedling populations and their parent genotypes. Plant Pathology 2008;57:210-5.

[17] Denoyes-Rothan B, Lerceteau-Köhler E, Guérin G, Bosseur S, Bariac J, Martin E, Roudeillac P. QTL analysis for resistances to Colletotrichum acutatum and Phytophthora cactorum in octoploid strawberry (Fragaria x ananassa). Acta Hort 2004;663:147-51. 
[18] Lederer W, Seemüller E. Untersuchungen zur Prädisposition der Erdbeere für die Rhizomfäule (Phytophthora cactorum). Zeitschrift für Pflanzenkrankheiten und Pflanzenschutz 1992;99:225-33.

[19] Lerceteau-Köhler E, Guérin G, Laigret F, Denoyes-Rothan B. Identification of SCAR markers linked to Rca2 anthracnose resistance gene and their assessment in strawberry germplasm. Theor Appl Genet 2005;111:862-70.

[20] Denoyes-Rothan B, Guérin G, Lerceteau-Köhler E, Risser G. Inheritance of Resistance to Colletotrichum acutatum in Fragaria x ananassa. Phytopathology 2005;95:405-12.

[21] Eikemo H, Klemsdal SS, Riisberg I, Bonants P, Stensvand A, Tronsmo AM. Genetic variation between Phytophthora cactorum isolates differing in their ability to cause crown rot in strawberry. Muycological Research 2004;108:317-24

[22] Lilja A, Karjalainen R, Parikka P, Kammiovirta K, Nuorteva H. Pathogenicity and genetic variation of Phytophthora cactorum from silver birch and strawberry. European Journal of Plant Pathology 1998;104:529-35

[23] Bell JA, Simpson DW, Harris DC. Development of a method for screening strawberry germplasm for resistance to Phytophthora cactorum. Acta Hort 1997;439:175-9.

[24] Darrow GM. The Strawberry: History, Breeding and Physiology. New York, NY, USA: Holt, Rinehart and Winston; 1966.

[25] Dale A, Sjulin TM. Few cytoplasms contribute to North American strawberry cultivars. HortScience 1990;25:1341-2.

[26] Gil-Ariza DJ, Iraida A, Lopez-Aranda JM, Sanchez-Sevilla JF, Botella MA, Valpuesta V. Impact of Plant Breeding on the Genetic Diversity of Cultivated Strawberry as Revealed by Expressed Sequence Tag-derived Simple Sequence Repeat Markers. Journal of the American Society of Horticultural Science 2009;134:337-47.

[27] Horvath A, Sánchez Sevilla JF, Punelli F, Sesmero Carrasco R, Leone A, Höefer M, Chartier P, Balsemin E, Barreneche T, Denoyes B. Structured diversity in octoploid strawberry cultivars highlights the importance of the old European germplasm. Annals of Applied Biology 2011. doi:10.1111/j.1744-7348.2011.00503.x

[28] Shulaev V, Sargent DJ, Crowhurst RN, Mockler TC, Folkerts O, Delcher AL, Jaiswal P, Mockaitis K, Liston A, Mane SP, Burn P, Davis TM, Slovin JP, Bassil N, Hellens RP, Evans C, Harkins T, Kodira C, Desany B, Crasta OR, Jensen RV, Allan AC, Michael TP, Setubal JC, Celton JM, Rees DJG, Williams KP, Holt SH, Rojas JJR Chatterjee M, Liu B, Silva H, Meisel L, Adato A, Filichkin S, Troggio R, Viola M, Ashman TL, Wang H, Dharmawardhana P, Elser J, Raja R, Priest HD, Bryant DWJr, Fox SE, Givan SA, Wilhelm LJ, Naithan S, Christoffels A, Salama DY, Carter J, Girona EL, Zdepski A, Wang W, Kerstetter RA, Schwab W, Korban SS, Davik J, Monfort A, Denoyes-Rothan B, Arus P, Mittler R, Flinn B, Aharoni A, Bennetzen JL, Salzberg SL, Dickerman AW, Velasco R, Borodovsky M, Veilleux RE, Folta KM. The genome of woodland strawberry (Fragaria vesca). Nature Genetics 2011;43(2):109-16. Epub. 2010; Dec 26.

[29] Rousseau-Gueutin M, Lerceteau-Köhler E, Barrot L, Sargent D, Monfort A, Simpson D, Arùs P, Guérin G, Denoyes-Rothan B. Comparative genetic mapping between octoploid and diploid Fragaria species reveals a high level of colinearity between their genomes and the essentially disomic behavior of the cultivated octoploid strawberry. Genetics 2008;179:2045-60.

[30] Rousseau-Gueutin M, Richard L, Le Dantec L, Denoyes-Rothan B. Development, mapping, and transferability of Fragaria EST-SSRs within the Rosodae supertribe. Plant Breeding 2010. doi:10.1111/j.1439-0523.2010.01785.x 